education, and who possess the additional advantage already referred to. Would it be too much to ask the members of the medical profession to give their votes to these gentlemen in their different districts as vacancies on the Council may arise, and thus, withoutimpairing their own representative, secure to the Merical Council that guidance in dental affairs which I believe they much need? I am, Sirs, yours obediently,

Nor. 3 rd, 1800.

$$
\text { J. S. TuRNER. }
$$

\section{HARVEY AS A PRACTICAL PHYSICIAN.} To the Editors of THE LANCET.

SIRs,-Whilst Dr. Andrew's eloquent Harveian lecture is fresh in the memory of those who had the advantage of hearing it, I think the following criticism of Harvey as a practical physician may be of interest. The quotation is taken from a shrewd but extremely ill-natured little book entitled "The Art of Curing Diseases by Expectation," published in 1689 by " one Gideon Harvey, M.D., "their Majesties' Physician of the Tower" (page 169).

After adjuring physicians not to "trifle away the best part of their time in needless Curiosities, and too fine spun Speculations of Anatomy," and after despairing that "He who has consumed the gross of his Time in Anatomy, or any other part of Physick, in neglect of Pharmacy, should ever come to be a good Physician," he tells the following anecdote of William Harvey: "The consult made a great noise when Dr. Wright and others together with the famed Dr. Harvey were principals ; and one Mrr. F. was Patient and Complainent of a painful Disease in his Belly, that deprived him of the use of his Limbs, Strength, Appetite, and Digestion, \&c. The forementioned Dr. Harvey ingrossed to himself the speaking part by reason of his extraordinary claim to Anatomy-and which here, if anywhere, seemed to be of use;--after a long contrectation of all the Abdomen did very magisterially and positively assert all his Symptoms to arise from an Aneurism of an Artery, and therefore incurable, as being too remote to come at. Wherein all, except Dr. Bates, very readily concur'd, though it was a most absur'd offer in opinion as ever I yet heard. The patient being unwilling to give up his cause so, removed his corpus cum causâ to Chelsie, where Sir 'Theodore Majerne lay bed-ridden at his country house, who upon no long examen of the matter told him ...... and very boldly expressed he would cure him ...... withont consulting the will and pleasure of God Almighty, an arrogancy unheard of, and savouring mose of the Atheist (as too many of 'em are) than a pious Physician, as then especially he ought to have beer, being not many stages from his journey's end.

You are to apprehend that the cause of this great Disease was an obstinate obstruction of the Glandrils of the Mesentery immensely swelled up, and hardened by coagulation of tartarous and slimy Humors, making a strong pressure upon the Arteria magna, which by a potent Renixe did duplicate its force of pulsation, that imposed on Dr. Harvey the false notion of an Aneurism, which ought rather to have been a Vibration. The conglobated tumor by compression causing a coarctation upon the Nerves, milkie and other Vessels, occasioned the great Weakness of his Limbs, an Atrophy, \&c., and by huffing up the Bowels against the Diaphragm, rendered his respiration extraordinary difficult." Sir Theodore fortunately had the success to dissolve those "gross glutinous Humors" by means of a "Grand empirical medicine" combined with "some gentle Purgatives," and to "throw them down into his Legz," whence the "Bath" removed them speedily.

The quotation seems to me to be of interest not only as a commentary on Dr. Andrew's remarks on the relationship which must exist between the physiologist and the physician, but also, in spite of Dr. Gideon Harvey's misguided notions of pathology, it shows his acquaintance with a disease to which Dr. Sidney Phillips has so lately drawn attention: I refer to the not uncommon cases of excessive aortic pulsation, associated with phantom abdominal tumours, which one meets in practice. The symptoms noted by Dr. Harvey are fully in accord with those described recently by Dr. Sidney Phillips, and they are doubtless due, as Dr. Phillips thinks, to some obscure condition of the great sympathetic ganglia in the abdomen. Vaso motor paralysis of the aorta explains the excessive pulsation. The soft gurglin tumours, which vary in position from day to day, and occasionally disappear entirely, may be regarded as local paralytic distensions of the large intestine. One of these cases was recently sent into a London hospital with the diagnosis of aneurysm of the abdominal aorta; another, in which the characteristic tumour was present, I lately found diagnosed as (1) hepatic cancer, and (2) distended gall bladder.

I am, Sirs, yours obediently, Leonard G. GUTIRIE, M B., M.R.C.P.

Upper George-street, W., Oct. 26th, 1890.

\section{HEALTH DIPLOMAS AND THE UNIVERSITY OF GLASGOW.}

\section{To the Editors of THE LANCET.}

SIRS,-In The LANCET of Saturday last you give a brief report of a meeting of the General Council of Glasgow University, at which a motion was submitted by Dr. Glaister regarding the diplomas in Public Health granted by the University last year. The writer of that report, no doubt unintentionally, fails to give a clear or fair idea of what transpired, as the verbatim report of the meeting that appeared in the Glasgow Herald, and which I send herewith, will show you. Your account of the matter says :"Dr. M'Vail attempted to address the meeting in favour of the resolution, but was met with such constant inter ruption that he resumed his seat amid a scene of general commotion. Eventually, order having been restored," \&c.

This undoubtedly must convey to your readers the impression that $I$ did not actually address the meeting, but only " attempted" to do so, and, further, that any words which, in spite of the "commotion," were heard by the meeting, must have been of an offensive nature. The Herald's report will show you : first, that I did actually address the meeting to the extent of considerably over half a column of closely printed report, amid interruption, no doubt; and secondly, that no words to which any fairminded person could take exception were uttered by me. Your report further conveys an inadequate idea of the chief points at issue, by failing to give the full text either of Dr. Glaister's motion or Dr. Duncan's amendment. As many of your readers are graduates of the University, and are vitally concerned in the maintenance of the prestige of its diplomas and degrees, I trust you will allow me to quote in full the motion and the amendment. The motion was as follows :-

"That this Council, being empowered by the Scottish Universities Acts to consider and take action upon all matters affecting the well being and prosperity of the University, has learned with regret the the examinations for diplomas in Public Health held in this University in October, 1839, finding that the said examinations were inadequate, and that the diplomas following thereupon were not worthy of registra tion and public recognition, concurs with said deliverance and finding deplores the action of the University court with regand to said diplomas, is of opinion that the circular letter of the coult to the diplomates of date July 2 nd, 1890, was inadequate to the circumstances of the case, and insufficient to re-establish the honour of the University, which cannot be satisfactorily effected otherwise than by procuring an Act of Parliament to cancel the said diplomas, and with that object appoints a committee with full powers to procure such an Act of Parliament."

Dr. Duncan's amendment to that resolution was as follows :-

"That this Council has learned with regret the deliverance of the General Medical Council of June, 1890, concerning the examination for diplomas in Public Health held in this University in October, 1889 finding that the said examinations were inadequate; but as the General Medical Council has by Act of Parliament full control over the recognition and registration of such diplomas, and has already dealt with this matter as it considered best for the public interestsand as the Glasgow University Court has made satisfactory arrangements, and appointed a competent Board of Examiners for a further ma time."

The chief point at issue between the motion and the amendment was as to the best method of reinstating the University as a health diploma-granting body in the conficlence of the country at large. II supported Dr. Glaister's resolution rather than the amendment for the following reasong, as you will see from my remarks reported in the Herald. The University Senate and the University Court and Dr. Duncan's amendment make no confession that the examination was inadequate, and Dr. Leishman characterised the evidence procured by the Medical Council as "of a most scant and superficial kind."

I thought it would be an error were the General Council of the University to concur in the view that, in spite of the General Medical Council's finding, there had been nothing 